\title{
Bowel frequency and symptoms of constipation and its relation with the level of physical activity in patients with Chagas disease
}

\author{
Daniela Carolina Barizon TEZA ${ }^{1}$, Érika Cristina FERREIRA ${ }^{1}$ and Mônica Lúcia GOMES ${ }^{2}$
}

Received: 11 December 2019 Accepted: 20 February 2020

\begin{abstract}
Background - Intestinal constipation (IC) in patients with the digestive form of Chagas disease is one of the main reasons for seeking medical care. Population data indicate that the practice of physical activity improves gastrointestinal motility. Objective - This study evaluated the bowel frequency and symptoms of constipation and their relationship with the level of physical activity in patients with and without Chagas disease. Methods - Patients ( $\mathrm{n}=120)$ of both genres, aged between 35 and 84 years, in which $50 \%(\mathrm{n}=60)$ were in the Chagas group and $50 \%(\mathrm{n}=60)$ were in the control group, were evaluated regarding the level of IC using the Constipation Assessment Scale (CAS) and regarding the level of physical activity using the International Physical Activity Questionnaire (IPAQ). Results - Patients in the Chagas group classified as active (IPAQ 2) had higher proportion $(P=0.0235)$ of moderate IC with severe abdominal distension $(P=0.0159)$ and decreased evacuation frequency $(P=0.0281)$ than the patients in the control group, considered to be very active (IPAQ 1). The sedentary lifestyle was greater $(P=0.0051)$ in the Chagas group with duration, intensity and frequency of physical activity lower than the control group. The health perception in the Chagas group was regular for $46.7 \%(P=0.0035)$ and poor for $8.3 \%(P=0.0244)$. Conclusion - There is a lower risk of developing intestinal constipation in more active individuals, evidencing that the level of physical activity interferes with bowel frequency and symptoms of constipation in patients with and without Chagas disease. The level of physical activity and health perception were worse in the Chagas group, reinforcing the disease stigma, which should be modified by the training of health professionals who routinely attend these patients.
\end{abstract}

HEADINGS - Chagas disease. Trypanosoma cruzi. Constipation. Exercise.

\section{INTRODUCTION}

Chagas disease is still a major public health problem, causing disability in infected individuals and more than 10,000 deaths per year ${ }^{(1)}$. Five to seven million people, mainly in Latin America, are infected with the protozoan Trypanosoma cruzi, the causative agent of this disease ${ }^{(1,2)}$. In Brazil, it was estimated in the year 2015 that a little more than 3 million individuals from the various Brazilian States are infected, predominantly in the Northeast, Central-west and Southeast regions ${ }^{(3)}$. The migration of these individuals to nonendemic countries has made this disease a global health problem ${ }^{(4)}$.

The digestive form of Chagas disease affects up to $10 \%$ of patients ${ }^{(5)}$. This form consists of dilation of the esophagus and colon due to neuronal destruction of the gastrointestinal tract and in the most severe cases causes malnutrition and chronic constipation ${ }^{(6)}$. This constipation has a slow and progressive evolution, starting with the difficulty of eliminating intestinal gases until the almost total impossibility for stool evacuation ${ }^{(6,7)}$. Intestinal constipation (IC) is one of the main reasons for seeking medical care, and the presence of complications in hospitalized patients increases the therapeutic costs for the public health system ${ }^{(7)}$. Population data indicate a lower frequency of constipation in individuals who practice more physical activity, as it improves gastrointestinal motility, with proportional alterations to the amount of activity practiced ${ }^{(8,9)}$. Studies involving these two variables related to preexisting diseases, such as Chagas disease, are necessary in order to propose interventions that minimize and control the problems related to the functional decline, and guide practices consistent with the reality of the population studied ${ }^{(4,5)}$. This requires practical, reliable, low-cost instruments with a considerable amount of information and easy application ${ }^{(10,11)}$. Questionnaires with an epidemiological approach and exploratory character are attractive $^{(12)}$. In this context, the Constipation Assessment Scale $(\mathrm{CAS})^{(11)}$ can be used together with the International Physical Activity Questionnaire (IPAQ), proposed by the World Health Organization in 1998 and validated in twelve countries, including Brazil ${ }^{(12)}$. Through these instruments, this study we evaluated the bowel frequency and symptoms of constipation and their relationship with the level of physical activity in patients with and without Chagas disease.

\section{METHODS}

\section{Study population}

A quantitative cross-sectional study was performed between July 2015 and July 2016 in two large municipalities, with population ranging from 300 to 600 thousand inhabitants, located in the North and Northwest regions of Paraná, Southern Brazil. The

Declared conflict of interest of all authors: non

Disclosure of funding: no funding received

${ }^{1}$ Universidade Estadual de Maringá, Centro de Ciências da Saúde, Programa de Pós-Graduação em Ciências da Saúde, Maringa, PR, Brasil. ${ }^{2}$ Universidade Estadual de Maringá, Departamento de Ciências Básicas da Saúde, Parasitologia, Maringá, PR, Brasil.

Corresponding author: Mônica Lúcia Gomes. E-mail: monicaluciagomes@gmail.com 
study population came from a spontaneous demand in the services where they were attended, consisting of 120 patients of both sexes, aged 35 to 85 years. Sixty patients without Chagas disease (control group) were treated at the outpatient clinic of the University Hospital of Maringá and 60 patients with clinical, laboratory diagnosis and the different clinical forms of Chagas disease (Chagas group) were treated by the Chagas Disease Laboratory of the Maringá State University (LDCh/UEM) and the Outpatient Clinic of the Northern Paraná Regional University Hospital - Londrina State University (HURNP/UEL). The patients were recruited through analysis and data collection from medical records and through individual interviews they were informed and invited to participate voluntarily in the study. Two questionnaires were applied to each patient, who signed the Free and Informed Consent Form, approved by the Ethics Committee in Research with Human Beings (COPEP) of the Maringá State University (registration 020938/2015) and by the Brazil Platform (Registration 43114115.9.0000.0104).

\section{Variables studied}

Bowel frequency and symptoms of constipation were assessed using the Constipation Assessment Scale (CAS), which identifies the presence and intensity of intestinal constipation. It consists of eight objective questions, involving the following themes: abdominal distension, alterations in gas elimination, lower frequency of evacuations, involuntary loss of liquid feces, full rectum or pressure sensation, rectal pain during evacuation, lower amount of feces elimination and desire and absence of evacuation. For each one of these themes, points were scored: zero (0) for no problem (absence of the symptom questioned), one (1) point for some problem (low intensity or frequency of the symptom) and two (2) points to severe problem (high intensity or frequency of the symptom). The sum of the scores resulted in the total score for each individual, in order to measure the presence and severity of IC. Thus, these values were arranged in strata, being as following: $0-3$, without IC; $4-7$, mild IC; 8-11, moderated IC; and 12-16, severe IC $^{(11)}$. The level of physical activity was evaluated using the International Physical Activity Questionnaire (IPAQ), short version, consisting of 8 open-ended questions about the time spent per week in different dimensions of physical activity (walking and physical exertion of moderate and vigorous intensity), and about physical inactivity (sitting position). The questions inquire about the frequency (days/week) and the time (minutes/day) spent for performing the activities. It is considered as vigorous the physical activity that requires great physical exertion and breathing much more intense than normal; and moderate, the physical activity that requires some physical effort and breathing a little more intense than normal. Thus, to assess the level of physical activity, the patients were classified in: I- Very Active or 1 : $\geq 30$ minutes/session of vigorous activity $\geq 5$ days/week; and/or $\geq 20$ minutes/session of vigorous activity $\geq 3$ days/week added to $\geq 30$ minutes/session of moderate activity or walking $\geq 5$ days/week; II- Active or 2: $\geq 20$ minutes/session of vigorous activity $\geq 3$ days/ week; and/or $\geq 30$ minutes/session of moderate activity or walking $\geq 5$ days/week; and/or $\geq 150$ minutes/week of any of the activities together (vigorous + moderate + walking); III- Irregularly Active A or 3: 150 minutes/week or 5 days/week of any of the activities together (vigorous + moderate + walking); IV- Irregularly Active B or 4: the patient who did not achieved any of the criteria of the recommendation regarding frequency or duration of activity and V-Sedentary or 5: $\leq 10$ minutes/week of any of the activities together (vigorous + moderate + walking) ${ }^{(12)}$.
The sociodemographic characteristics (genre, marital status, age, smoking, alcoholism, workload and schooling), associated pathologies and health perception were also investigated.

\section{Statistical analysis}

The data obtained were entered into a spreadsheet of the software Microsoft Excel 2010 and were statistically analyzed using the Software Statistica 8.0. Means and standard deviations were evaluated for the quantitative variables, followed by the Mann-Whitney test for comparison of the groups Chagas and control. For the qualitative variables, in turn, we used double-entry frequency tables with percentage followed by the $\mathrm{Z}$ test. The level of significance adopted in the tests was $5 \%$, that is, associations with $P<0.05$ were considered significant.

\section{RESULTS}

In both groups, the largest number of patients were female, married and aged between 50 and 64 years and reported no associated pathologies. In the Chagas group, there was a higher proportion of patients who do not work outside the home $(P=0.0070)$, who had a basic level of education $(P=0.0282)$ and the perception of health as regular $(P=0.0395)$ or bad $(P=0.0244)$. In the control group, the proportion of patients working up to 5 hours/day $(P=0.0198)$ and having higher education $(P=0.0001)$ was higher (TABLE 1$)$.

The relationship between the level of physical activity and the degree of intestinal constipation identified that patients in the Chagas group classified as active (IPAQ 2) had a higher proportion of moderate intestinal constipation $(P=0.0235)$ than control group patients who were very active (IPAQ 1$)$ and had no intestinal constipation $(P=0.0019)$ (TABLE 2$)$.

Moderate intestinal constipation prevailed in patients from the Chagas group $(P=0.0244)$ compared to the control group (TABLE $3)$. A higher proportion of Chagas group patients reported severe abdominal distension problem $(P=0.0159)$ and lower bowel movement frequency $(P=0.0281)$ and control group patients had no abdominal distension problem $(P=0.0183)$ and inability to eliminate stool $(P=0.0174)$ (TABLE 4$)$.

The Chagas group presented a higher proportion of sedentary people $(P=0.0051)$ and the control group of active individuals $(P=0.0282)$ (TABLE 3$)$. The intensity $(P=0.0001)$ and the frequency of moderate physical activity $(P=0.0001)$ and the duration of walking $(P=0.0013)$ were significantly lower in the Chagas group (TABLE 5).

\section{DISCUSSION}

In the present study we investigated the bowel frequency and symptoms of constipation and their relationship with the level of physical activity in patients with and without Chagas disease and showed that intestinal constipation was more severe in the Chagas group, especially regarding abdominal distension and the frequency of intestinal movement. In this group the level of physical activity was lower compared to the control group, identifying a relationship between physical activity and bowel frequency and symptoms of constipation, that is, less active patients present greater impairment of intestinal frequency and functioning. The contemporary lifestyle, which predisposes to the limitation of physical activities (such as the use of remote control, computers, video games, television, elevator, etc.), and which contribute to the reduction of efforts in daily tasks, tend to decrease the frequency and functioning intestinal ${ }^{(13,14)}$, especially with regard to pre-existing diseases such as Chagas disease. 
TABLE 1. Distribution of Chagas and control groups according to the variables evaluated in the patients.

\begin{tabular}{|c|c|c|c|c|c|}
\hline \multirow{3}{*}{ Variables } & \multicolumn{4}{|c|}{ Groups } & \multirow{3}{*}{$P$} \\
\hline & \multicolumn{2}{|c|}{ Chagas $(n=60)$} & \multicolumn{2}{|c|}{ Control $(n=60)$} & \\
\hline & $\mathrm{n}$ & $\%$ & $\mathrm{n}$ & $\%$ & \\
\hline
\end{tabular}

\section{Genre}

\section{Female}

Male

Marital status

$\begin{array}{lccccc}\text { Married } & 43 & 71.7 & 39 & 65.0 & 0.4317 \\ \text { Widower } & 5 & 8.3 & 12 & 20.0 & 0.0685 \\ \text { Divorced } & 8 & 13.3 & 5 & 8.3 & 0.3794 \\ \text { Single } & 4 & 6.7 & 4 & 6.7 & 0.9999\end{array}$

Age range

$\begin{array}{llllll}35 \text { to } 49 \text { years old } & 11 & 18.3 & 12 & 20.0 & 0.8133 \\ 50 \text { to } 64 \text { years old } & 27 & 45.0 & 31 & 51.7 & 0.4642 \\ 65 \text { years or older } & 22 & 36.7 & 17 & 28.3 & 0.3280\end{array}$

Smoker

$\begin{array}{lccccc}\text { Yes } & 3 & 5.0 & 7 & 11.7 & 0.1872 \\ \text { No } & 40 & 66.7 & 47 & 78.3 & 0.1574 \\ \text { Former smoker } & 17 & 28.3 & 6 & 10.0 & 0.0121 * \\ \text { Ethylist } & & & & & \\ \text { No } & 59 & 98.3 & 60 & 100.0 & 0.3125 \\ \text { Former alcoholist } & 1 & 1.7 & 0 & 0.0 & 0.3125\end{array}$

Workload

$\begin{array}{lccccc}\text { Don't work out } & 15 & 25.0 & 4 & 6.7 & 0.0070 * \\ \text { Up to 5 hours } & 6 & 10.0 & 16 & 26.7 & 0.019 *^{*} \\ 6 \text { to } 8 \text { hours } & 36 & 60.0 & 29 & 48.3 & 0.2009 \\ 9 \text { hours or more } & 3 & 5.0 & 11 & 18.3 & 0.0250 *\end{array}$

Schooling

\begin{tabular}{lccccc} 
No schooling & 5 & 8.3 & 3 & 5.0 & 0.4696 \\
Elementary school & 41 & 68.3 & 29 & 48.3 & $0.0282^{*}$ \\
High school & 12 & 20.0 & 9 & 15.0 & 0.4725 \\
Higher education & 2 & 3.3 & 19 & 31.7 & $0.0001^{*}$ \\
Health perception & & & & & \\
Bad & 5 & 8.3 & 0 & 0.0 & $0.0244^{*}$ \\
Regular & 28 & 46.7 & 17 & 28.3 & $0.0395 *$ \\
Good & 20 & 33.3 & 29 & 48.3 & 0.0972 \\
Very good & 1 & 1.7 & 6 & 10.0 & 0.0551 \\
Great & 6 & 10 & 8 & 13.3 & 0.5742 \\
\hline
\end{tabular}

* Significant $\mathrm{Z}$ test considering 5\% significance level.
TABLE 2. Relation between the level of intestinal constipation and level of physical activity of patients in groups Chagas and control.

\begin{tabular}{|c|c|c|c|c|c|c|}
\hline \multirow{3}{*}{ CAS } & \multirow{3}{*}{ IPAQ } & \multicolumn{4}{|c|}{ Groups } & \multirow{3}{*}{$P$} \\
\hline & & \multicolumn{2}{|c|}{ Chagas $(n=60)$} & \multicolumn{2}{|c|}{ Control $(n=60)$} & \\
\hline & & $\mathrm{n}$ & $\%$ & $\mathrm{n}$ & $\%$ & \\
\hline Without IC & 1 & 4 & 8.2 & 15 & 30.6 & $0.0019 *$ \\
\hline Without IC & 2 & 23 & 46.9 & 20 & 40.8 & 0.5007 \\
\hline Without IC & 3 & 5 & 10.2 & 4 & 8.2 & 0.7047 \\
\hline Without IC & 4 & 9 & 18.4 & 5 & 10.2 & 0.1995 \\
\hline Without IC & 5 & 2 & 4.1 & 5 & 10.2 & 0.1947 \\
\hline Total & & 43 & 87.8 & 49 & 100.0 & - \\
\hline Mild IC & 1 & 2 & 4.1 & 1 & 2.0 & 0.5036 \\
\hline Mild IC & 2 & 3 & 6.1 & 8 & 16.3 & 0.0765 \\
\hline Mild IC & 3 & 1 & 2.0 & 0 & 0.0 & 0.2709 \\
\hline Mild IC & 4 & 1 & 2.0 & 1 & 2.0 & 0.999 \\
\hline Mild IC & 5 & 3 & 6.1 & 0 & 0.0 & 0.0520 \\
\hline Total & & 10 & 20.4 & 10 & 20.4 & - \\
\hline Moderate IC & 1 & 0 & 0.0 & 0 & 0.0 & 0.9999 \\
\hline Moderate IC & 2 & 4 & 8.2 & 0 & 0.0 & $0.0235 *$ \\
\hline Moderate IC & 3 & 0 & 0.0 & 0 & 0.0 & 0.999 \\
\hline Moderate IC & 4 & 1 & 2.0 & 1 & 0.0 & 0.2709 \\
\hline Moderate IC & 5 & 0 & 0.0 & 0 & 0.0 & 0.9999 \\
\hline Total & & 5 & 10.2 & 0 & 0.0 & - \\
\hline Severe IC & 1 & 1 & 2.0 & 0 & 0.0 & 0.2709 \\
\hline Severe IC & 2 & 0 & 0.0 & 1 & 2.0 & 0.2709 \\
\hline Severe IC & 4 & 0 & 0.0 & 0 & 0.0 & 0.9999 \\
\hline Severe IC & 3 & 0 & 0.0 & 0 & 0.0 & 0.9999 \\
\hline Severe IC & 5 & 1 & 2.0 & 0 & 0.0 & 0.2709 \\
\hline Total & & 2 & 4.1 & 1 & 2.0 & - \\
\hline
\end{tabular}

* Significant Z test considering significance level of 5\%. CAS: Constipation Assessment Scale; IPAQ: International Physical Activity Questionnaire. $1=$ very active; $2=$ active; $3=$ irregular A; $4=$ irregular B; $5=$ sedentary.

TABLE 3. Classification of the level of intestinal constipation and level of physical activity of the patients in groups Chagas and control.

\begin{tabular}{|c|c|c|c|c|c|}
\hline \multirow{3}{*}{ Variables } & \multicolumn{4}{|c|}{ Groups } & \multirow{3}{*}{$P$} \\
\hline & \multicolumn{2}{|c|}{ Chagas $(n=60)$} & \multicolumn{2}{|c|}{ Control $(n=60)$} & \\
\hline & $\mathrm{n}$ & $\%$ & $\mathrm{n}$ & $\%$ & \\
\hline \multicolumn{6}{|l|}{ CAS classification } \\
\hline Without CI & 43 & 71.7 & 50 & 83.3 & 0.1308 \\
\hline Mild IC & 10 & 16.7 & 9 & 15.0 & 0.7992 \\
\hline Moderated IC & 5 & 8.3 & 0 & 0.0 & $0.0244 *$ \\
\hline Severe IC & 2 & 3.3 & 1 & 1.7 & 0.5756 \\
\hline \multicolumn{6}{|c|}{ IPAQ classification } \\
\hline 1- Very active & 2 & 3.3 & 5 & 8.3 & 0.2437 \\
\hline 2- Active & 29 & 48.3 & 41 & 68.3 & $0.0282 *$ \\
\hline 3-Irregular A & 6 & 10.0 & 2 & 3.3 & 0.1434 \\
\hline 4- Irregular B & 11 & 18.3 & 10 & 16.7 & 0.8180 \\
\hline 5- Sedentary & 12 & 20.0 & 2 & 3.3 & $0.0051 *$ \\
\hline
\end{tabular}

* Significant $\mathrm{Z}$ test considering significance level of $5 \%$. IC: intestinal constipation; CAS: Constipation Assessment Scale; IPAQ: International Physical Activity Questionnaire. 
TABLE 4. Distribution of the characteristics of the Constipation Assessment Scale (CAS) according to the variable intensity of intestinal constipation in the patients in groups Chagas and control.

\begin{tabular}{|c|c|c|c|c|c|}
\hline \multirow{3}{*}{ Variables } & \multicolumn{4}{|c|}{ Groups } & \multirow{3}{*}{$P$} \\
\hline & \multicolumn{2}{|c|}{ Chagas $(n=60)$} & \multicolumn{2}{|c|}{ Control $(n=60)$} & \\
\hline & $\mathrm{n}$ & $\%$ & $\mathrm{n}$ & $\%$ & \\
\hline \multicolumn{6}{|c|}{ Abdominal distension } \\
\hline No problem & 27 & 45.0 & 40 & 66.7 & $0.0183 *$ \\
\hline Some problem & 23 & 38.3 & 18 & 30.0 & 0.339 \\
\hline Serious problem & 10 & 16.7 & 2 & 3.3 & $0.0159 *$ \\
\hline \multicolumn{6}{|c|}{ Alteration in the amount of gas elimination } \\
\hline No problem & 36 & 60.0 & 45 & 75.0 & 0.0820 \\
\hline Some problem & 18 & 30.0 & 13 & 21.7 & 0.3012 \\
\hline Serious problem & 6 & 10.0 & 2 & 3.3 & 0.1434 \\
\hline \multicolumn{6}{|c|}{ Lower evacuation frequency } \\
\hline No problem & 41 & 68.3 & 43 & 71.7 & 0.6852 \\
\hline Some problem & 10 & 16.7 & 15 & 25.0 & 0.2654 \\
\hline Serious problem & 9 & 15.0 & 2 & 3.3 & $0.0281 *$ \\
\hline \multicolumn{6}{|l|}{ Loss of liquid feces } \\
\hline No problem & 49 & 81.7 & 56 & 93.3 & 0.0571 \\
\hline Some problem & 7 & 11.7 & 3 & 5.0 & 0.1872 \\
\hline Serious problem & 4 & 6.7 & 1 & 1.7 & 0.1748 \\
\hline \multicolumn{6}{|c|}{ Pressure or rectal repression sensation } \\
\hline No problem & 53 & 88.3 & 53 & 88.3 & 0.9999 \\
\hline Some problem & 2 & 3.3 & 6 & 10.0 & 0.1434 \\
\hline Grave problem & 5 & 8.3 & 1 & 1.7 & 0.0998 \\
\hline \multicolumn{6}{|c|}{ Rectal pain during evacuation } \\
\hline No problem & 52 & 86.7 & 52 & 86.7 & 0.9999 \\
\hline Some problem & 3 & 5.0 & 7 & 11.7 & 0.1872 \\
\hline Serious problem & 5 & 8.3 & 1 & 1.7 & 0.0998 \\
\hline \multicolumn{6}{|c|}{ Evacuation of low amount of feces } \\
\hline No problem & 45 & 75.0 & 53 & 88.3 & 0.0623 \\
\hline Some problem & 11 & 18.3 & 6 & 10.0 & 0.1947 \\
\hline Serious problem & 4 & 6.7 & 1 & 1.7 & 0.1748 \\
\hline \multicolumn{6}{|c|}{ Inability of eliminating feces } \\
\hline No problem & 52 & 86.7 & 59 & 98.3 & $0.0174 *$ \\
\hline Some problem & 5 & 8.3 & 1 & 1.7 & 0.0998 \\
\hline Serious problem & 3 & 5.0 & 0 & 0.0 & 0.0820 \\
\hline
\end{tabular}

* There is a difference between the proportions by the $\mathrm{Z}$ test considering the level of significance of $5 \%$.
Another result in the present study helping to evidence this relation between physical activity and bowel frequency and symptoms of constipation is the high percentage (46.9\%) of individuals in Chagas group considered active (IPAQ 2) who did not have intestinal constipation. Researches indicate that individuals who practice more physical activity have a lower frequency of intestinal constipation ${ }^{(15)}$, mainly due to the fact that physical activity improves gastrointestinal motility by stimulating peristalsis, improving pelvic and abdominal muscle tone, improving the intestinal pattern and consequently facilitating to expel the fecal bolus $^{(16)}$, that is, physical activity is such a protective factor against intestinal constipation ${ }^{(16,17)}$. Patients with Chagas disease are able and should perform physical activities, which, in addition to promoting improvements in cardiopulmonary function ${ }^{(17,18)}$, may also improve the functioning of the gastrointestinal tract, according to the recommendations for management of intestinal constipation proposed by the American Association of Gastroenterology, which suggests the regular practice of physical activity ${ }^{(19,20)}$.

Physical inactivity was more pronounced in the Chagas group. A randomized clinical trial showed that sedentary patients who maintained their lifestyle for 12 weeks had a higher degree of constipation and total colonic and rectosigmoid transit time than those who underwent regular physical training program for 12 weeks, confirming the influence beneficial of regular physical activity ${ }^{(20)}$.

The duration, intensity and frequency of physical activity was shorter for patients in the Chagas group. The type, intensity and frequency of the activity performed significantly interfere with the response to infection ${ }^{(20,21)}$. The difference between the intensity of exercise performance is that moderate physical activity, even during infection, may not alter or improve the host immune response in both viral and parasitic infections ${ }^{(21,22)}$. In a study that a moderate intensity physical training program was applied in BALB/c mice, physical exercise was able to improve the body's response to T. cruzi infection, significantly reducing parasitemia peak and increasing survival ${ }^{(21)}$.

In addition to the lower level of physical activity, the most severe constipation in the Chagas group may be related to the fact that $T$. cruzi infection promotes the destruction of enteric nervous system (SNE) nerve cells, and as a consequence, changes in the digestive system ${ }^{(22,23)}$. The SNE is located on the walls of the gastrointestinal tract and consists of about 100 million neurons, from

TABLE 5. Distribution of IPAQ variables - duration (D), intensity (I) and frequency (F) of physical activity in patients in groups Chagas and control.

\begin{tabular}{|c|c|c|c|c|c|c|c|}
\hline Variables & Groups & $\mathrm{n}$ & Mean & \pm Standard deviation & Minimum & Maximum & $P$ \\
\hline \multirow{2}{*}{$\begin{array}{l}\text { Walking D } \\
\text { (minutes) }\end{array}$} & Control & 60 & 44.4 & \pm 24.3 & 0.0 & 90.0 & \multirow{2}{*}{$0.0013^{*}$} \\
\hline & Chagas & 60 & 29.6 & \pm 23.8 & 0.0 & 90.0 & \\
\hline Walking F (days) & Chagas & 60 & 2.9 & \pm 2.3 & 0.0 & 7.0 & 0.0597 \\
\hline \multirow{2}{*}{$\begin{array}{l}\text { Moderate I D } \\
\text { (minutes) }\end{array}$} & Control & 60 & 45.3 & \pm 29.0 & 0.0 & 180.0 & \multirow{2}{*}{$0.0001 *$} \\
\hline & Chagas & 60 & 19.2 & \pm 22.3 & 0.0 & 90.0 & \\
\hline Moderate I F (days) & Chagas & 60 & 2.2 & \pm 2.5 & 0.0 & 7.0 & $0.0001 *$ \\
\hline \multirow{2}{*}{$\begin{array}{l}\text { Vigourus I D } \\
\text { (minutes) }\end{array}$} & Controle & 60 & 12.6 & \pm 21.8 & 0.0 & 60.0 & \multirow{2}{*}{0.0672} \\
\hline & Chagas & 60 & 6.0 & \pm 16.0 & 0.0 & 60.0 & \\
\hline \multirow{2}{*}{ Vigourus I F (days) } & Controle & 60 & 0.8 & \pm 1.5 & 0.0 & 7.0 & \multirow{2}{*}{0.0542} \\
\hline & Chagas & 60 & 0.3 & \pm 0.9 & 0.0 & 5.0 & \\
\hline
\end{tabular}

* Significant Mann-Whitney test considering significance level of 5\%; IPAQ: International Physical Activity Questionnaire. 
the esophagus to the anus and has the function of integrating and coordinating the different visceral functions ${ }^{(24)}$. Auerbach's plexus is the structure most affected by the inflammatory process triggered by $T$. cruzi infection, as it is located in the viscera wall, causing a marked reduction in the number of nerve cells ${ }^{(25,26)}$.

In the Chagas group, the number of more inactive individuals was higher, reaffirming the stigma of the disease (which has no cure, which can lead to death, especially if some physical effort, etc. $)^{(27)}$. Another result of the present study that emphasizes this issue is that in the Chagas group a high percentage $(55 \%)$ of patients rated their health as fair or poor when compared to the control group. In addition to undergoing a sudden change in their physical and mental health, the patient still suffers the repercussions of the disease in their life context ${ }^{(28)}$. The involvement of psychological aspects has been reported by several authors, emphasizing that the patient, upon learning about the disease, develops a reactive symptomatology, such as depression and anxiety ${ }^{(29,30)}$. This process is triggered by the hidden fear of malignant evolution and the impossibility of stopping the disease ${ }^{(29)}$. In this sense, the association of mental and psychic manifestations with Chagas disease, regardless of the clinical form presented, influence the evolution of the disease and the lives of patients ${ }^{(30)}$.

In the Chagas group, the predominance of individuals with low educational level and who did not work outside the home or had lower workload, evidences the "weight" for patients who are carriers of a neglected disease that affects a less favored portion of society in addition to have fewer employment opportunities ${ }^{(31)}$. Other studies also demonstrated that the patients with Chagas disease have low educational level ${ }^{(32,33)}$ and are mistakenly rejected when seeking employment, simply because they have a positive serology for T. cruzi, despite having the same work capacity as the individuals without Chagas disease ${ }^{(34,35)}$. Since it is a pathology of considerable social and economic impact, it is necessary to inform the population about the evolution of the disease, to train healthcare teams to instruct patients and to demystify the disease, stimulating the habitual practice of physical activity as an essential component for the establishment of an ideal health status ${ }^{(36,37)}$.

The results in the present study allow us to conclude that: bowel frequency and symptoms of constipation of the patient with and without Chagas disease is related to the level of physical activity; the level of intestinal constipation was significantly more pronounced in patients with Chagas disease, because they presented a severe abdominal distension problem and reduced evacuation frequency, which can be prevented by instructions programs in primary health care; the patients with Chagas disease were more sedentary, since they had shorter duration, intensity and frequency of physical activity; these patients had lower educational level, lower workload outside the home and worse levels of health perception, reinforcing the level of the disease stigma, which should be modified by the training of healthcare professionals who routinely attend these patients.

\section{Authors' contribution}

Teza DCB: study concept and design, drafting the manuscript, data collect and drafting the manuscript. Gomes ML: critical revision of the manuscript for important intellectual content. Ferreira EC: statistical review of manuscript.

\section{Orcid}

Daniela Carolina Barizon Teza: 0000-0003-0733-206X.

Érika Cristina Ferreira: 0000-0002-1890-4943.

Mônica Lúcia Gomes: 0000-0001-5701-5375.

Teza DCB, Ferreira EC, Gomes ML. Frequência intestinal e sintomas de constipação e sua relação com o nível de atividade física em pacientes com doença de Chagas. Arq Gastroenterol. 2020;57(2):161-6.

RESUMO - Contexto - A constipação intestinal (CI) em pacientes com a forma digestiva da doença de Chagas é uma das principais razões para procura de atendimento médico. Os dados populacionais indicam que a prática de atividade física melhora a motilidade gastrointestinal. Objetivo- Este estudo avaliou a frequência intestinal e os sintomas de constipação e sua relação com o nível de atividade física em pacientes com e sem doença de Chagas. Métodos - Pacientes ( $\mathrm{n}=120)$ de ambos os gêneros, com idades entre 35 e 84 anos, nos quais $50 \%(n=60)$ eram do grupo Chagas e $50 \%$ ( $\mathrm{n}=60)$ do grupo controle, foram avaliados quanto ao nível da CI utilizando a Escala de Avaliação da Constipação (CAS) e o nível de atividade física utilizando o Questionário Internacional de Atividade Física (IPAQ). Resultados - Os pacientes do grupo Chagas classificados como ativos (IPAQ 2) apresentaram maior proporção $(P=0,0235)$ de CI moderada com distensão abdominal grave $(P=0,0159)$ e frequência de evacuação diminuída $(P=0,0281)$ do que os pacientes do grupo controle, considerados muito ativos (IPAQ 1). O estilo de vida sedentário foi maior $(P=0,0051)$ no grupo Chagas com duração, intensidade e frequência de atividade física menor que o grupo controle. A percepção de saúde no grupo Chagas foi regular para $46,7 \%(P=0,0035)$ e ruim para $8,3 \%(P=0,0244)$. Conclusão - Existe menor risco de desenvolver constipação intestinal em indivíduos mais ativos, evidenciando que o nível de atividade física interfere na frequência intestinal e nos sintomas de constipação em pacientes com e sem doença de Chagas. O nível de atividade física e percepção de saúde foram piores no grupo Chagas, reforçando o estigma da doença, que deve ser modificado pela capacitação dos profissionais de saúde que atendem rotineiramente esses pacientes.

DESCRITORES - Doença de Chagas. Trypanosoma cruzi. Constipação intestinal. Exercício físico. 


\section{REFERENCES}

1. World Health Organization - WHO. Chagas disease in Latin America: an epidemiological update based on 2010 estimates. Wkly Epidemiol Rec 2015;90:33-44.

2. World Health Organization - WHO. Physical activity 2016. [Internet]. [Access 2017 January 20]. Available from: http://www.who.int/mediacentre/factsheets fs $385 /$ en/.

3. Dias JCP, Ramos ANJ, Gontijo ED, Luquetti A, Shikanai-Yasuda MA, Coura JR, et al. II Consenso Brasileiro em Doença de Chagas 2015. Epidemiol Serv Saúde. 2016;25:7-86.

4. Schmunis GA, Yadon ZE. Chagas disease: a Latin American health problem becoming a world health problem. Acta Trop. 2010;115:14-21.

5. Centers For Disease Control And Prevention (CDC). Parasites - American Trypanosomiasis (also known as Chagas Disease): Epidemiology \& Risk Factor 2013. [Internet]. [Access 2016 September 16]. Available from: http://www.cdc. gov/parasites/chagas/epi.html.

6. Santos JCMJ. Constipação Intestinal. Rev Bras Colo-proctol. 2005;5:79-93.

7. Gullo CE, Estofolete CF, Gil CD, Christiano AB. Digestive forms of Chagas disease and carcinogenesis: a study of association. Rev Col Bras Cir. 2012;39: 146-50.

8. Dukas L, Walter CW, Giovannucci EL. Association between physical activity, fiber intake, and other lifestyle variables and constipation in study of women. Am J Gastroenterology. 2003;98:1790-6.

9. Muller LSA, Kamm MA, Scarpignato C, Wald A. Myths and misconception about chronic constipation. Am J Gastroenterol. 2005;100:232-42.

10. Kohl HW, Craing CL, Lambert EV, Inoue S, Alkandari JR, Leetongin G, et al The pandemic of physical inactivity: global action for public health. Lancet. 2012;21:294-305

11. McMillan SC, Williams FA. Validity and reliability of the constipation assessment scale. Cancer Nurs.1989;12:183-8.

12. Matsudo S, Araújo T, Matsudo V, Andrade D, Andrade E, Oliveira LC, et al Questionário Internacional de Atividade Física (IPAQ): estudo de validade e reprodutibilidade no Brasil. Rev Bras Ativ Fís Saúde. 2001;6:5-18.

13. Guedes DP, Lopes CC, Guedes, J. Reprodutibilidade e validade do Questionário Internacional de Atividade Física em adolescentes. Rev Bras Med Esporte. 2005;11:151-8.

14. Collete VL, Araújo CL, Magruga SW. Prevalência e fatores associados à constipação intestinal: um estudo de base populacional em Pelotas, Rio Grande do Sul, Brasil, 2007. Cad Saúde Pública. 2010;26:1391-402.

15. Simren M. Physical activity and the gastrointestinal tract. Eur J Gastroenterol Hepatol. 2002;14:1053-6.

16. Driessen LM, Jong JCK, Wijtzes A, Vries SI, Jaddoe VWV, Hofman A, et al. Physical activity and functional constipation during the preschool period: the generation R study. J Pediat Gastr Nutr. 2013;57:768-74.

17. Mendes MAF, Lopes WS, Nogueira GA, Wilson A, Araujo SM, Gomes ML. Exercício físico aeróbico em mulheres com doença de Chagas. Fisioter Mov. 2011;24:591-601.

18. Lopes WL, Ferreira EC, Silva SS, Tomiotto-Pellissier F, Costa IC, Pavanelli WR, et al. Physical training improves cardiopulmonary functional capacity and increases cytokine IL-10 levels in individuals with Chagas disease. Trop J Pharm Research. 2017;16:1319-26.
19. Locke GR, Pemberton JH, Phillips SF. AGA technical review on constipation. Gastroenterology. 2000;119:1766-78.

20. Schryver AM, Keulemans YC, Peters HP, Akkermans LM. Effects of regular physical activity on defecation pattern in middle-aged patients complaining of chronic constipation. Scand J Gastroenterol. 2005;40:422-9.

21. Schebeleski CS, Soares RCO, Moraes SMF, Dalalio MMO, Almeida FN, Toledo $\mathrm{MJO}$, et al. Preinfection aerobic treadmill training improves resistance agains Trypanosoma cruzi infection in mice. Appl Physiol Nutr Met. 2009;34:659-65.

22. Lowder T, Padgett DA, Woods JA. Moderate exercise early after influenza virus infection reduces the Thl inflammatory response in lungs of mice. Exerc Immunol Rev. 2006;12:97-111

23. Lowder T, Padgett DA, Woods JA. Moderate exercise protects mice from death due to influenza virus. Brain Behav Immun. 2005;19:377-80.

24. Guyton AC, Hall J. Tratado de Fisiologia Médica. 11 ed. Rio de Janeiro: Elsevier 2006

25. Pinto JJ, Pinazo MJ, Saravia J, Gainsborg I, Magne HR, Cuatrecasas M, et al Characterization of digestive disorders of patients with chronic Chagas disease in Cochabamba, Bolivia. Helion. 2019;5:120-6.

26. Guillén BP, Lugo AY, Moreno E. Dilatación del tracto digestivo de ratones infectados con Trypanosoma cruzi. Rev Invest Clínica. 2001;24:195-209.

27. Guariento ME, Camilo MVF, Camargo AMA. Situação trabalhista do portador de doença de Chagas crônica, em um grande centro urbano. Cad Saúde Pública. 1999;15:381-6.

28. Amato MS, Neto AV, Uip DE. Avaliação da qualidade de vida de pacientes com doença de Chagas submetidos a transplante de coração. Rev Soc Bras Med Trop. 1997:30:159-60.

29. Mota DCGA, Pereira AMTB, Gomes ML, Araújo SM. Estresse e resiliência em doença de Chagas. Aletheia. 2006;24:57-68.

30. Mangone CA, Sica REP, Pereyra S. Cognitive impairment in human chronic Chagas disease. Arq Neuropsiquiatr 1994;52:200-203.

31. Storino R, Auger S, Jörg M, Martino MS, Urrutia MI. Aspectos biológicos, psicológicos y sociales de la discriminación del paciente chagásico en Argentina. Rev Salud Pública. 2002;4:258-69.

32. Oliveira FAS, Bicalho GVC, Filho LDS, Silva MJ, Filho ZCG Características epidemiológicas dos pacientes com doença de Chagas. Rev Bras Med Farmac Comun. 2006;2:107-13.

33. Gontijo ED, Rocha MOC, Oliveira UT. Perfil clínico-epidemiológico de chagásicos atendidos em ambulatório de referência de modelo de atenção ao chagásico na perspectiva do SUS. Rev Soc Bras Med Trop. 1996;29:101-8.

34. Dias JCP. Globalização, iniquidade e doença de Chagas. Cad Saúde Pública. 2007;23:13-22

35. Ronan L, Souza LRMF, Freitas GL. Evolução de pacientes chagásicos acompanhados em um serviço de referência. Rev Soc Bras Med Trop. 2000;33:111-3.

36. Lopes WS, Cuman RKN, Guedes TA, Araujo SM, Gomes ML. Exercício aeróbio reduz a hipertensão arterial de mulheres com Doença de Chagas. Rev Bras Med Esporte. 2014;20:131-6.

37. Bielmann RM, Silva BGC, Coll CVN, Xavier MO, Silva SG. Impacto da inatividade física e custos de hospitalização por doenças crônicas. Rev Saúde Pública 2015;49:75-82. 